\title{
Mesozooplankton influences on the microbial food web: Direct and indirect trophic interactions in the oligotrophic open ocean
}

\author{
Albert Calbet and Michael R. Landry \\ Department of Oceanography, University of Hawaii at Manoa, 1000 Pope Road, Honolulu, Hawaii 96822
}

\begin{abstract}
The phytoplankton in warm oligotrophic regions of the open oceans is dominated by $<2-\mu \mathrm{m}$ cells too small for efficient direct consumption by mesozooplankton. However, these primary producers are hypothetically linked to higher trophic levels via the cascading impacts of mesozooplankton grazing on intermediate consumers. To assess the magnitudes of these indirect trophic linkages, grazing experiments, involving different concentration treatments of the mixed mesozooplankton community, were performed during cruises in the subtropical North Pacific at station ALOHA. Mesozooplankton fed on a diverse assemblage of microzooplankton and nanoheterotrophs $>5 \mu \mathrm{m}$, and their predation indirectly enhanced net growth rates of phytoplankton and $2-5-\mu \mathrm{m}$ heterotrophs. Increasing the concentration of mesozooplankton also enhanced growth rates of heterotrophic bacteria, but this was more likely the result of organic enrichment than trophic transfer. Scaled to their natural abundance, the indirect grazing impacts of mesozooplankton on lower trophic levels are small, accounting for $<0.005 \mathrm{~d}^{-1}$ of the growth rates of each prey category examined. Thus, the larger consumers appear to exert little net influence on the dynamics at the base of the food web. In contrast, size-fraction manipulations of consumers between 2 and $20 \mu \mathrm{m}$ (i.e., the nanozooplankton) elicited strong responses among bacterial populations indicative of tightly coupled predatory chain of at least two steps. Given the present results, detailed studies of the interactions among pico- and nanoplankton appear to be the most profitable avenue for improving our understanding of community structure and function in this region and for acquiring useful data for developing and validating ecosystem models of the open oceans.
\end{abstract}

Warm oligotrophic waters of the subtropical North Pacific support a complex planktonic community with pico-sized $(0.2-2 \mu \mathrm{m})$ phytoplankton providing most of the primary production and combined auto- and heterotrophic bacteria dominating community biomass (Campbell and Vaulot 1993; Letelier et al. 1993; Campbell et al. 1994, 1997). Such organisms are largely unavailable to direct utilization by the crustacean-dominated mesozooplankton because of size constraints on feeding mechanisms (Rassoulzadegan and Etienne 1981; Conover 1982; Berggreen et al. 1988; Hansen et al. 1994). Nonetheless, they are linked in principle to higher order animals by the cascading influences of mesozooplankton grazing on consumers of intermediate size (Sherr et al. 1986; Sherr and Sherr 1988; Wikner and Hagström 1988).

The strong coupling of nonadjacent trophic levels via indirect cascade effects is a well-established phenomenon in freshwater systems, where the presence or absence of piscivorous fish can profoundly influence zooplankton community composition, phytoplankton abundance, water clarity, heat budgets, and mixing depth (Carpenter et al. 1985; McQueen et al. 1986; Kerfoot 1987; Mazumder et al. 1990;

\section{Acknowledgments}

We are grateful to the captain and the crew of the R/V Moana Wave for their help in making the work possible even in rough weather conditions. We also thank S. Christensen and S. Nunnery for their assistance with the experiments, H. Nolla for his patience in the teaching of flow cytometric techniques, and J. Constantinou for his logistical support and comments on the first version of the manuscript. This work was supported by National Science Foundation grant OCE-9218152 to M.R.L. and a postdoctoral fellowship (EX96-46651369) from the Ministerio de Educación y Cultura (Spain) to A.C. Contributions 4772 from the School of Ocean and Earth Science and Technology, University of Hawaii at Manoa and 504 from the U.S. JGOFS Program.
Pace et al. 1998). In contrast, this area has received little attention in marine systems, despite recent evidence that the harvesting of the oceans is systematically diminishing the average trophic level of top consumers and concerns about long-term shifts in community structure (Dayton et al. 1995; Myers et al. 1997; Pauly et al. 1998).

The subtropical open oceans represent the oligotrophic extreme in the spectrum of marine ecosystems and are consequently an unlikely place to expect cascade effects related to fisheries. Nonetheless, such systems are vastly important on a global scale and generally the least studied of all marine systems with regard to community trophic structure and function. Moreover, because of the presence of U.S. Joint Global Ocean Flux Study (JGOFS) time-series monitoring programs in the subtropical Atlantic and Pacific Oceans, these regions have become an important focus of efforts to develop models of open-ocean ecosystems (e.g., Doney et al. 1996; Hurtt and Armstrong 1996; Lawson et al. 1996). The present study examines the hypothetical coupling among food web components from bacteria to mesozooplankton in the subtropical north Pacific. Our specific goal was to quantify direct and indirect influences of mesozooplankton on lower levels of the food web. In addition, we sought to begin to establish a deeper understanding of trophic interactions that would be relevant to modeling data needs for this region.

Materials and methods

Study sites-The present experimental work was conducted on shipboard during spring and summer cruises of the JGOFS Hawaii Ocean Time-series (HOT) Program. The main sampling site was Stn. ALOHA $\left(22.75^{\circ} \mathrm{N}, 158^{\circ} \mathrm{W}\right)$, approximately $100 \mathrm{~km}$ north of the island of Oahu, Hawaii 
Table 1. Initial conditions for zooplankton grazing experiments. Water was collected from the surface (2 m) or deep chlorophyll maximum (105-120 m), and experiments focused on grazing of the MESO (200-2,000- $\mu \mathrm{m})$ or MICRO (60-200- $\mu \mathrm{m})$ size fractions. HBACT, 2-5 HNAN, and $>5$ HNAN denote initial abundances (cells $/ \mathrm{ml}$ ) for heterotrophic bacteria, 2-5- $\mu \mathrm{m}$ heterotrophs, and $>5-\mu \mathrm{m}$ heterotrophs, respectively. Chlorophyll estimates are given as concentrations $(\mu \mathrm{g} / \mathrm{L})$ of the $<2-\mu \mathrm{m}$ size fraction $(<2$ Chl $a)$, the community total (Tot $\mathrm{Chl} a$ ), and the $\%$ of total $<2 \mu \mathrm{m}$. Values in parentheses are standard errors of mean estimates.

\begin{tabular}{|c|c|c|c|c|c|c|c|c|}
\hline Date & Depth (m) & Grazers & HBACT & 2-5 HNAN & $>5$ HNAN & $<2 \mathrm{Chl} a$ & Tot Chl $a$ & $\%<2 \mathrm{Chl}$ \\
\hline 4 June & 120 & MESO+MICRO & $\begin{array}{c}3.0 \times 10^{5} \\
\left(0.4 \times 10^{5}\right)\end{array}$ & $\begin{array}{r}110 \\
(4)\end{array}$ & $\begin{array}{l}23 \\
(1)\end{array}$ & $\begin{array}{c}0.169 \\
(0.025)\end{array}$ & $\begin{array}{c}0.177 \\
(0.022)\end{array}$ & 95.5 \\
\hline 26 June & 105 & MESO & $\begin{array}{c}1.6 \times 10^{5} \\
\left(0.2 \times 10^{5}\right)\end{array}$ & $\begin{array}{l}51 \\
(8)\end{array}$ & $\begin{array}{l}20 \\
(1)\end{array}$ & $\begin{array}{c}0.290 \\
(0.021)\end{array}$ & $\begin{array}{c}0.297 \\
(0.019)\end{array}$ & 97.6 \\
\hline 8 July & 2 & MESO & $\begin{array}{c}5.7 \times 10^{5} \\
\left(0.5 \times 10^{5}\right)\end{array}$ & $\begin{array}{l}108 \\
(15)\end{array}$ & $\begin{array}{l}25 \\
(4)\end{array}$ & $\begin{array}{c}0.042 \\
(0.001)\end{array}$ & $\begin{array}{c}0.071 \\
(0.001)\end{array}$ & 59.1 \\
\hline 9 July & 115 & MESO & $\begin{array}{c}4.6 \times 10^{5} \\
\left(0.1 \times 10^{5}\right)\end{array}$ & $\begin{array}{l}55 \\
(8)\end{array}$ & $\begin{array}{l}17 \\
(1)\end{array}$ & $\begin{array}{c}0.169 \\
(0.016)\end{array}$ & $\begin{array}{c}0.215 \\
(0.010)\end{array}$ & 78.6 \\
\hline 10 July & 120 & MICRO & $\begin{array}{c}4.4 \times 10^{5} \\
\left(0.6 \times 10^{5}\right)\end{array}$ & $\begin{array}{c}91 \\
(14)\end{array}$ & $\begin{array}{l}15 \\
(4)\end{array}$ & $\begin{array}{c}0.154 \\
(0.001)\end{array}$ & $\begin{array}{c}0.166 \\
(0.010)\end{array}$ & 92.7 \\
\hline 1 August & 2 & MESO & $\begin{array}{c}7.8 \times 10^{5} \\
\left(0.1 \times 10^{5}\right)\end{array}$ & $\begin{array}{l}221 \\
(47)\end{array}$ & $\begin{array}{l}31 \\
(6)\end{array}$ & $\begin{array}{c}0.034 \\
(0.001)\end{array}$ & $\begin{array}{c}0.052 \\
(0.030)\end{array}$ & 65.4 \\
\hline
\end{tabular}

(Karl and Lukas 1996). However, one experiment (8 July, Table 1) used water collected at the Kahe Point test station $\left(21.48^{\circ} \mathrm{N}, 158.37^{\circ} \mathrm{W} ; 15 \mathrm{~km}\right.$ west of Oahu). These locations have been sampled approximately monthly since 1988 and are considered representative of the oligotrophic subtropical Pacific with regard to the abundance, biomass, and production of the plankton community (Campbell and Vaulot 1993; Letelier et al. 1993; Campbell et al. 1997).

Microbial food web interactions-Experimental incubations with prescreened seawater were used to identify the size fractions of consumers most responsible for direct grazing impact on picoplankton populations. Water from the deep chlorophyll maximum (DCM) at $110 \mathrm{~m}$ was prefiltered through polycarbonate membrane filters of varying pore size $(1,2,5,8$, and $20 \mu \mathrm{m})$ and placed in $250-\mathrm{ml}$ polystyrene culture flasks (Corning). Four replicate flasks were prepared for each size-fractionated treatment, and an additional four flasks were run with unfiltered natural seawater (controls). The flasks were incubated for $24 \mathrm{~h}$ in a seawater-cooled incubator screened with neutral density fabric to $1 \%$ of surface light intensity. Before and after the incubation, 2-ml subsamples were preserved with paraformaldehyde $(0.2 \%$ final concentration), frozen in liquid nitrogen, and stored at $-85^{\circ} \mathrm{C}$ (Vaulot et al. 1989). These subsamples were subsequently thawed and stained with Hoechst $33342\left(1 \mu \mathrm{g} \mathrm{ml}^{-1}\right.$ ) (Monger and Landry 1993), and population abundances of heterotrophic bacteria and Prochlorococcus sp. were enumerated using a Coulter EPICS 753 flow cytometer equipped with two 5-W argon lasers, an MSDS volume-control sampling, and Cytomation CICERO software (Campbell et al. 1997). Net growth rates of the bacterial populations in the different treatments were computed from the ratios of initial and final abundance estimates assuming exponential rates of increase or decrease during the incubation.

Direct feeding interactions of metazooplankton-Three experiments were conducted on 4 June 1997 to assess the direct feeding impacts of net-collected meso- and microzooplankton on phytoplankton and the predatory preferences of mesozooplankton feeding on microzooplankton. Mesozooplankton (MESO $=$ animals in the $200-2,000-\mu \mathrm{m}$ size fraction) were collected using a $1-\mathrm{m}^{2}$ plankton net with $200-\mu \mathrm{m}$ mesh and 7-liter bag as a nonfiltering cod end. Microzooplankton $(\mathrm{MICRO}=$ net-collected zooplankton in the 60$200-\mu \mathrm{m}$ size fraction; in this study dominated by copepod nauplii and codepodites) were collected using a 0.5 -m-diameter plankton net with $60-\mu \mathrm{m}$ mesh. Both nets were towed obliquely from $100 \mathrm{~m}$ to the surface at about 1 knot. Once on deck, the contents of the cod-end bags were carefully poured into a 10-liter insulated container, and experimental organisms were gently sorted by reverse flow through 15$\mathrm{cm}$ submerged sieves of 200 or 2,000 $\mu \mathrm{m}$ mesh for MICRO and MESO, respectively. Only free-swimming and healthy organisms that passed through the respective sieves were used in the experiments.

For the grazing experiments on phytoplankton, aliquots of each zooplankton size fraction $(0.9 \mathrm{mg}$ dry weight for MI$\mathrm{CRO}$ and $4.8 \mathrm{mg}$ dry weight for MESO) were placed into 2.3-liter polycarbonate bottles filled with water from the deep chlorophyll maximum (DCM) collected from 110 to $120 \mathrm{~m}$ depth with Niskin bottles on a CTD rosette. This water was filtered through 60 - and $200-\mu \mathrm{m}$ mesh for the MICRO and MESO experiments to remove ambient grazers in the respective size fractions. Nitrate $\left.(4.5 \mu \mathrm{M} \mathrm{NaNO})_{3}\right)$ was added to all bottles to override differences in zooplankton excretion among treatments. Four replicates and three controls without zooplankton were prepared per treatment. An additional group of three bottles was filled with water filtered through a $2-\mu \mathrm{m}$ polycarbonate membrane filter to assess phytoplankton growth without grazers larger than $2 \mu \mathrm{m}$. The incubations began at night and were run for $14 \mathrm{~h}$ in a seawater-cooled incubator screened to $1 \%$ of surface irradiance. The bottles were gently mixed one or two times during the incubations to reduce settling. Subsamples of the water were taken for chlorophyll analyses in triplicate at the start of the 
experiments and from each bottle at the end. For each subsample, an aliquot of $150 \mathrm{ml}$ was filtered thorough a GF/F filter (total chlorophyll $a[\mathrm{Chl} a]$ ), and a similar aliquot was prefiltered through a $2-\mu \mathrm{m}$ polycarbonate membrane before $\mathrm{GF} / \mathrm{F}$ filtration $(<2 \mu \mathrm{m} \mathrm{Chl} a)$. The filters were initially frozen in liquid nitrogen and later extracted for $48 \mathrm{~h}$ in $90 \%$ acetone and analyzed on a Turner fluorometer by standard techniques (Strickland and Parsons 1972). Net instantaneous growth rates of the two chlorophyll fractions were estimated from initial and final concentrations assuming exponential rates of change during the incubations.

Incubations to assess the predatory pressure and possible prey selection of MESO feeding on MICRO were prepared in 2.3-liter bottles filled with surface seawater and aliquots of $4.9 \mathrm{mg}$ dry weight of MESO. The treatments consisted of four different concentrations of MICRO, with three replicates and two controls without MESO for each treatment. Following the 14-h incubations, the organisms were retained on a $40-\mu \mathrm{m}$ submerged sieve and fixed with formalin $(5 \%$ final concentration). The retained animals were enumerated in the laboratory using a dissecting microscope, and ingestion rates were calculated according the equations of Frost (1972) as modified by Landry (1978). Interpretation of these experiments was simplified by negligible changes in MICRO abundances in control bottles.

Cascading effects of zooplankton grazing-To quantify the effects of zooplankton grazing on lower levels of the food web, we measured the net growth rate responses of identifiable auto- and heterotrophic populations to increasing concentration of grazers (Lehman 1980). It was expected that the relationships between net growth rates of given size fractions and grazer concentration would alternate between negative and positive trends for successively lower trophic levels.

The experimental set-up was essentially similar to that described for direct grazing effects. Polycarbonate bottles (2.3-liter) were filled with either DCM (26 June, 9-10 July) or surface (8 July, 1 August) water amended with a nutrient mixture $\left(4.5 \mu \mathrm{M} \mathrm{NaNO}, 0.5 \mu \mathrm{M} \mathrm{NH} \mathrm{NH}_{4} \mathrm{Cl}\right.$, and $0.2 \mu \mathrm{M}$ $\mathrm{NaH}_{2} \mathrm{PO}_{4}$ ) to compensate for differential effects of zooplankton excretion in the treatments. Aliquots of MESO or MICRO (10 July only) were added to two replicate bottles per treatment and up to five treatments per experiment; in addition, three control bottles were prepared without animals. Comparable aliquots of MESO or MICRO were frozen in liquid nitrogen at the beginning of each experiment for later assessment of dry weight of the added zooplankton.

The incubations were conducted as previously described $\left(1 \%\right.$ light, $\left.26 \pm 0.5^{\circ} \mathrm{C}\right)$ and lasted for $12-18 \mathrm{~h}$, always including the nighttime. At the beginnings and ends of the incubations, the bottles were subsampled for Chl $a$, heterotrophic bacteria (HBACT), and nanoheterotrophs (HNAN). Chl $a$ and HBACT samples were taken and analyzed as described above. For heterotrophic nanoplankton, 250-ml samples were preserved with $125 \mu \mathrm{l}$ of alkaline Lugol's fixative ( $0.05 \%$ final concentration), followed immediately with the addition of $5 \mathrm{ml}$ of borate-buffered formalin ( $2 \%$ final concentration) and $250 \mu \mathrm{l}$ of sodium thiosulfate ( $0.3 \%$ final concentration) to clear the iodine color (Sherr and Sherr 1993).

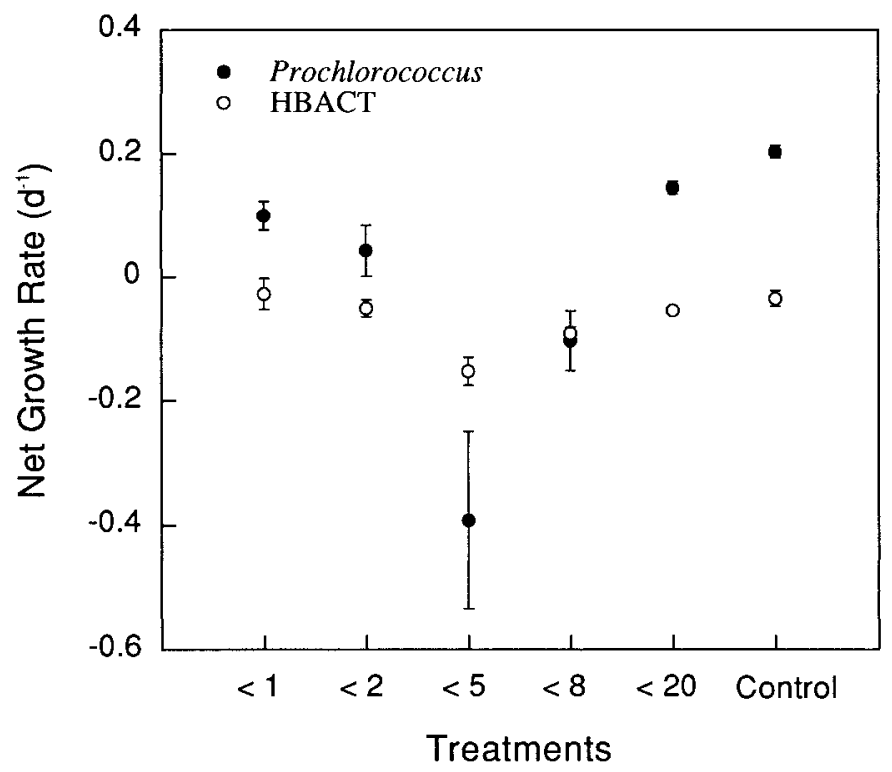

Fig. 1. Effects of removal of different size classes of protistan consumers on net growth rates of heterotrophic bacteria (HBACT) and Prochlorococcus in the subtropical north Pacific. Treatments are seawater samples filtered through polycarbonate membrane filters of $1-20-\mu \mathrm{m}$ pore size prior to incubation; control $=$ unfiltered sample. Vertical bars show standard errors of four replicates.

After fixation, the samples were momentarily stained with proflavin $(12 \mu \mathrm{g} / \mathrm{ml}$ final concentration), then stained with DAPI ( $8 \mu \mathrm{g} \mathrm{ml}^{-1}$ final concentration) for a few seconds and filtered onto $2-\mu \mathrm{m}$ pore-size black polycarbonate membrane filters ( $3 \mu \mathrm{m}$ for $8-9$ July, 1 August). The filters were mounted in immersion oil (type B) on slides and kept frozen until analysis with a color image-analysis system consisting of a Zeiss epifluorescence microscope with a ZVS 3-chip chargecoupled device video camera connected to a computer. The images were analyzed using a Zeiss Image Pro Plus software to facilitate counting and sizing of all heterotrophic and autotrophic organisms. About 300 individuals were enumerated and sized for each sample. We present the results in two size fractions: heterotrophs between 2 and $5 \mu \mathrm{m}$ (hereafter called $2-5 \mu \mathrm{m}$ HNAN) and heterotrophs larger than $5 \mu \mathrm{m}(>5 \mu \mathrm{m}$ HNAN). Autotrophic organisms in the larger size fraction were not sufficiently abundant for meaningful statistical analyses; therefore, these organisms are included more accurately in the Chl $a$ size fractions. The results (net growth rates vs. MESO or MICRO biomass) were fit to linear regressions (Lehman 1980). Where necessary, ANCOVA tests were performed to detect significant differences between regression lines.

\section{Results}

Grazing on bacteria and bacterivores-Food web linkages in the microbial component of the plankton community are illustrated by the net growth rates of heterotrophic and phototrophic (Prochlorococcus sp.) bacteria in the various size-fractionated treatments (Fig. 1). Removal of the $>20$ $\mu \mathrm{m}$ consumers resulted in only a slight decline in bacterial 
net growth, suggesting that ambient concentrations of microzooplankton had little direct impact on lower trophic levels or that their effects are broadly distributed among organisms of different size. In contrast, removal of organisms in the 5-20- $\mu \mathrm{m}$ size range resulted in substantial decreases in net growth rates of bacteria. The decrease was particularly spectacular for Prochlorococcus (approximately $-0.6 \mathrm{~d}^{-1}$ ) and less so for HBACT that dominate biomass and presumably grow much slower on average than autotrophic cells in the open oligotrophic ocean (Fuhrman et al. 1989; Cho and Azam 1990).

In comparison to the effects of the 5-20- $\mu \mathrm{m}$ fraction, successive removal of organisms $>2 \mu \mathrm{m}$ and $>1 \mu \mathrm{m}$ increased net bacterial growth rates, restoring them to only slightly less than they were in unfiltered controls (Fig. 1). Most of this positive net effect on bacterial growth was achieved following removal of the $2-5-\mu \mathrm{m}$ fraction. Such results suggest that bacteria are principally the prey of consumers in the 2 5- $\mu \mathrm{m}$ fraction (2-5 $\mu \mathrm{m}$ HNAN). In turn, these "bacterivores" appear to be grazed by $>5-\mu \mathrm{m}$ nanoplankton $(>5$ HNAN). The breakdown of the community into $<2-\mu \mathrm{m}, 2-$ $5-\mu \mathrm{m}$, and $>5-\mu \mathrm{m}$ fractions is carried over to meso- and microzooplankton experiments discussed below.

Composition of the microbial plankton community-Table 1 summarizes the size structure of the microbial community at the study site during June-August 1997. HBACT varied from 1.6 to $7.810^{5}$ cells $\mathrm{ml}^{-1}$, being typically more abundant in surface waters than in the DCM. This trend was also evident for other components of the heterotrophic community but opposite for Chl $a$, presumably due to photoadaptation of cellular pigment content. Heterotrophs in the 2-5$\mu \mathrm{m}$ size range varied from 50 to 220 cells $\mathrm{ml}^{-1}$, exceeding $>5 \mu \mathrm{m}$ HNAN on average by a factor of 4.7 (range 2.67.1). Total Chl $a$ varied from 0.05 to $0.3 \mu \mathrm{g} \mathrm{L}^{-1}$, and the $<2-\mu \mathrm{m}$ fraction represented $91 \%$ of the total on average for experiments involving water from the DCM and $62 \%$ of the total for surface water.

Initial grazing experiments-Initial grazing experiments with MICRO and MESO showed marked contrasts in chlorophyll responses among treatments (Fig. 2). In the $2-\mu \mathrm{m}$ prescreened incubations, chlorophyll net growth was positive $\left(\approx 0.3 \mathrm{~d}^{-1}\right)$ and comparable to the Prochlorococcus growth noted previously when all grazers were removed (Fig. 1). Prescreening of the water with either 200- or $60-\mu \mathrm{m}$ mesh removed the larger size categories of grazers, MESO or MESO+MICRO, respectively, leaving the microbial portion of the food web, including most heterotrophic protists, intact. Under these circumstances and the low light levels of the experimental incubations, net growth rates of $<2-\mu \mathrm{m}$ picophytoplankton were strongly negative, about $-0.5 \mathrm{~d}^{-1}$. The addition of either MESO or MICRO grazers to treatment bottles containing the protistan assemblage enhanced the net growth rates of picophytoplankton relative to controls, although the rates were still negative and substantially less than those when all grazers $>2 \mu \mathrm{m}$ were removed.

While MESO and MICRO showed comparable effects on the $<2-\mu \mathrm{m}$ chlorophyll fraction, their impacts on total chlorophyll were different (Fig. 2). Total Chl $a$ grew at a low,

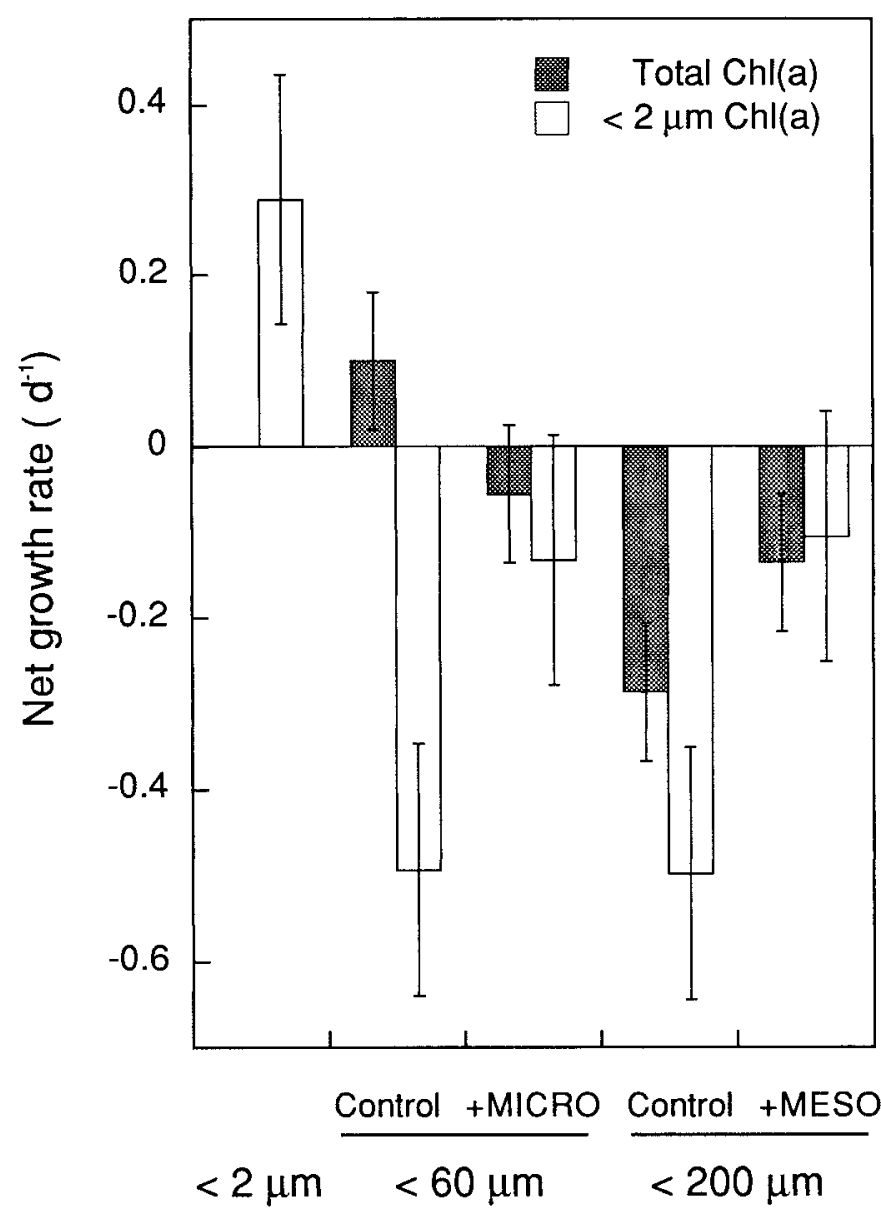

Fig. 2. Impacts of micro- and mesozooplankton grazers on net growth rates of total and $<2-\mu \mathrm{m}$ Chl $a$ in the subtropical north Pacific. Treatments are $<2-\mu \mathrm{m}$ filtered water, $<60-\mu \mathrm{m}$ filtered water with and without $0.4 \mathrm{mg}$ dry wt. MICRO L ${ }^{-1}$, and $<200-\mu \mathrm{m}$ filtered water with and without $2.1 \mathrm{mg}$ dry wt MESO L ${ }^{-1}$. Vertical bars show standard errors of three (without MESO or MICRO) or four (with MESO or MICRO) replicates.

but net positive rate in water prescreened to remove both MICRO and MESO fractions, and the addition of MICRO resulted in a slightly negative net rate. In comparison, net growth of total Chl $a$ in the absence of MESO was more negative than with added MESO.

Ingestion rates of MESO feeding on MICRO are shown in Fig. 3. Only data for copepod nauplii and copepodites are presented because other organisms, like ciliates or dinoflagellates, were too rare for statistically reliable enumeration. MESO showed a clear feeding preference for copepodites over nauplii. Due to the large difference in mean sizes of these potential prey organisms, the twofold predatory preference for copepodites is substantially greater in terms of biomass consumed.

The trophic cascade-The indirect food web effects implied in the 4 June experiments (Fig. 2) were investigated on subsequent cruises over a range of grazer concentrations (Figs. 4, 5). In the experiments conducted in this manner, the slopes of individual regression analyses of net prey 


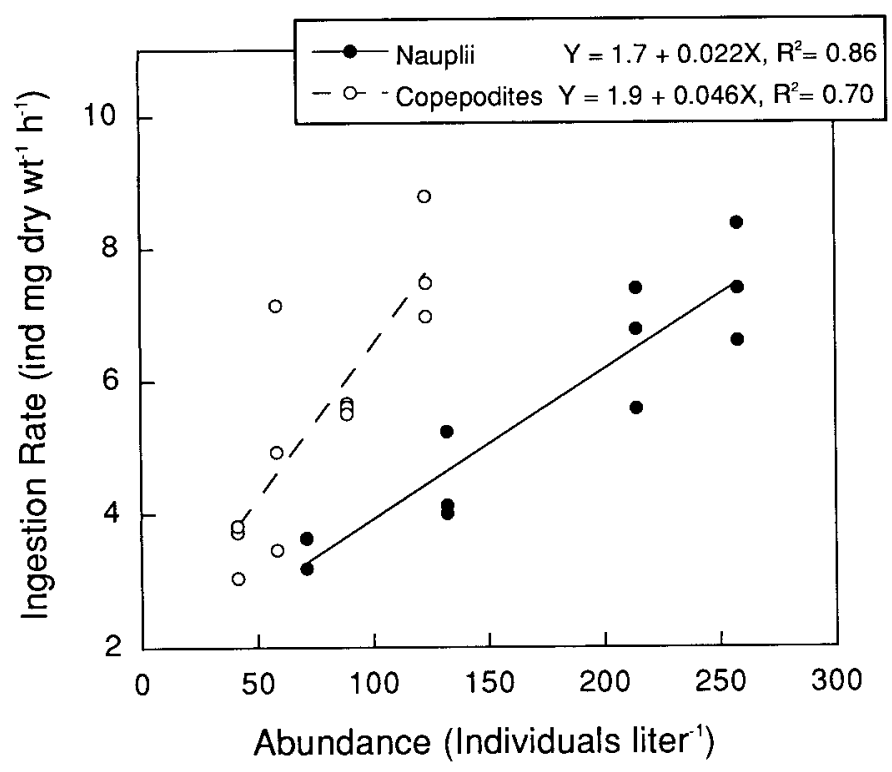

Fig. 3. Functional relationships between ingestion rates of mesozooplankton (prey consumed $\mathrm{mg}$ dry $\mathrm{wt}^{-1} \mathrm{~h}^{-1}$ ) and abundances of nauplii (open symbols) and copepodites (dark symbols) in the subtropical north Pacific.

growth rate versus increasing grazer biomass were frequently not significantly different from zero. However, the slopes were consistently positive or negative for individual prey categories, and the mean slope for each prey type was significant at either $P<0.05$ or $P<0.01$ (Table 2).

Among pigmented cells, both the $<2-\mu \mathrm{m} \mathrm{Chl} a$ size fraction and abundances of Prochlorococcus showed weakly positive (means $=0.05$ and $0.02 \mathrm{~L} \mathrm{mg}$ dry $\mathrm{wt}^{-1} \mathrm{~d}^{-1}$, respectively) and generally insignificant trends with increasing MESO or MICRO biomass (Table 2). The $>2-\mu \mathrm{m}$ Chl $a$ fraction responded more dramatically (mean $=0.40 \mathrm{~L} \mathrm{mg}$ dry $\left.\mathrm{wt}^{-1} \mathrm{~d}^{-1}\right)$. The projected net growth rates in the absence of large grazers (i.e., the $Y$-intercepts of the regression equations) were variable but always positive for larger phytoplankton. For the $<2-\mu \mathrm{m}$ Chl $a$ fraction, net growth rates ranged between -0.4 and $+0.5 \mathrm{~d}^{-1}$, being positive for experiments conducted with surface water and negative with water from the DCM. These consistent differences in growth rate intercepts (Table 3) most likely reflect photoadaptive effects, as the dominant pigmented organism in this size category, Prochlorococcus, showed relatively low net rates of change in cell abundance $\left(-0.1\right.$ to $\left.0.15 \mathrm{~d}^{-1}\right)$ during the incubations and no difference between deep and shallow samples (Table 2). The main difference in the responses of lower trophic levels to variations in biomass of MESO versus MICRO grazers was in the $>2-\mu \mathrm{m} \mathrm{Chl} a$. The net growth rate intercept was higher when MESO was varied, but the net growth enhancement effect was almost threefold higher ( 0.89 versus $0.30 \mathrm{~L} \mathrm{mg}$ dry $\left.\mathrm{wt}^{-1} \mathrm{~d}^{-1}\right)$ when MICRO biomass was increased (Tables 2, 3).

Among heterotrophic populations, net growth rates of HBACT and 2-5- $\mu \mathrm{m}$ HNAN were enhanced by increasing concentrations of MESO or MICRO (means $=0.26$ and 0.49 $\mathrm{L} m \mathrm{~g}$ dry $\mathrm{wt}^{-1} \mathrm{~d}^{-1}$, respectively), but $>5-\mu \mathrm{m}$ HNAN de- creased (mean $=-0.23 \mathrm{~L} \mathrm{mg}$ dry $\left.\mathrm{wt}^{-1} \mathrm{~d}^{-1}\right)($ Fig. 5, Table 2). No significant differences were found between MESO and MICRO experiments except for the HBACT intercept (Table 3). The regression slopes for HBACT and 2-5- $\mu \mathrm{m}$ HNAN were similar for experiments conducted with DCM water (26 June, 9 and 10 July). However, the net growth responses of 2-5- $\mu \mathrm{m}$ HNAN exceeded HBACT by 3-11fold in experiments with surface water ( 8 July, 1 August).

\section{Discussion}

Food web organization-Among the clearest results of the present study were the effects of removing various size fractions of heterotrophic nanoplankton on the net growth rates of picoplankton (Fig. 1). Removing consumers between 5 and $20 \mu \mathrm{m}$ had a significant negative effect on the net growth of HBACT and particularly Prochlorococcus, while removing the $2-5-\mu \mathrm{m}$ HNAN caused the net rates to return to control levels. These results suggest strong trophic linkages at the base of the food web-from picoplankton to $<5$ $\mu \mathrm{m}$ HNAN that consume bacterial-sized food, to 5-20- $\mu \mathrm{m}$ HNAN that keep bacterivores in check.

Within the micro- and mesozooplankton size categories, the food web linkages become more diffuse and unstructured. For example, both net-collected MICRO and MESO exerted a direct grazing impact (i.e., negative influence) upon $>5-\mu$ m HNAN (Fig. 5). In addition, MESO showed a strong preference for preying on larger MICRO (Fig. 3). The simplest scenario consistent with these results is for MICRO to feed mainly on the larger HNAN, while MESO feed broadly on prey in the $5-200-\mu \mathrm{m}$ range. Protistan microzooplankton (e.g., ciliates) occur in these waters, but their abundances are typically well below $1 \mathrm{cell} \mathrm{ml}^{-1}$ and their biomass is vastly outweighed by smaller flagellates (Beers et al. 1975). If the grazing role of larger protists was substantial, we would have expected to see a larger response when $>20-\mu \mathrm{m}$ cells were removed by size fractionation (Fig. 1). Moreover, if protists occupied a significant intermediate trophic link between net-collected MICRO and larger HNAN, increasing concentrations of MICRO grazers should have resulted in an increase in $>5-\mu \mathrm{m}$ HNAN. Because neither of these effects was observed, we conclude that the protistan grazing pathway is reasonably well represented by two levels within the nanoplankton size category.

The trophic structure elucidated by the present experiments differs from the fixed 10-fold ratio of predator:prey sizes as originally proposed for the microbial loop by Azam et al. (1983). If the predator: prey size ratio was a factor of 10 by linear dimension, HBACT (mean equivalent spherical diameter $[\mathrm{ESD}] \approx 0.5 \mu \mathrm{m}$ ) and Prochlorococcus (mean ESD $\approx 0.7 \mu \mathrm{m}$ ) would be consumed by HNAN in the $5-7-\mu \mathrm{m}$ range, and they in turn would be preyed upon by protistan microplankton of 50-70 $\mu \mathrm{m}$ size. The trophic structure suggested by Fig. 1 is in better agreement with a predator:prey size ratio on the order of 3 to 4 for flagellates, as summarized by Hansen et al. (1994). An average ratio of 4 would yield bacterivores of about $2.4 \mu \mathrm{m}$ and secondary consumers of about $10 \mu \mathrm{m}$. In experiments in which predation rates on bacterial-sized particles were measured directly in size-frac- 

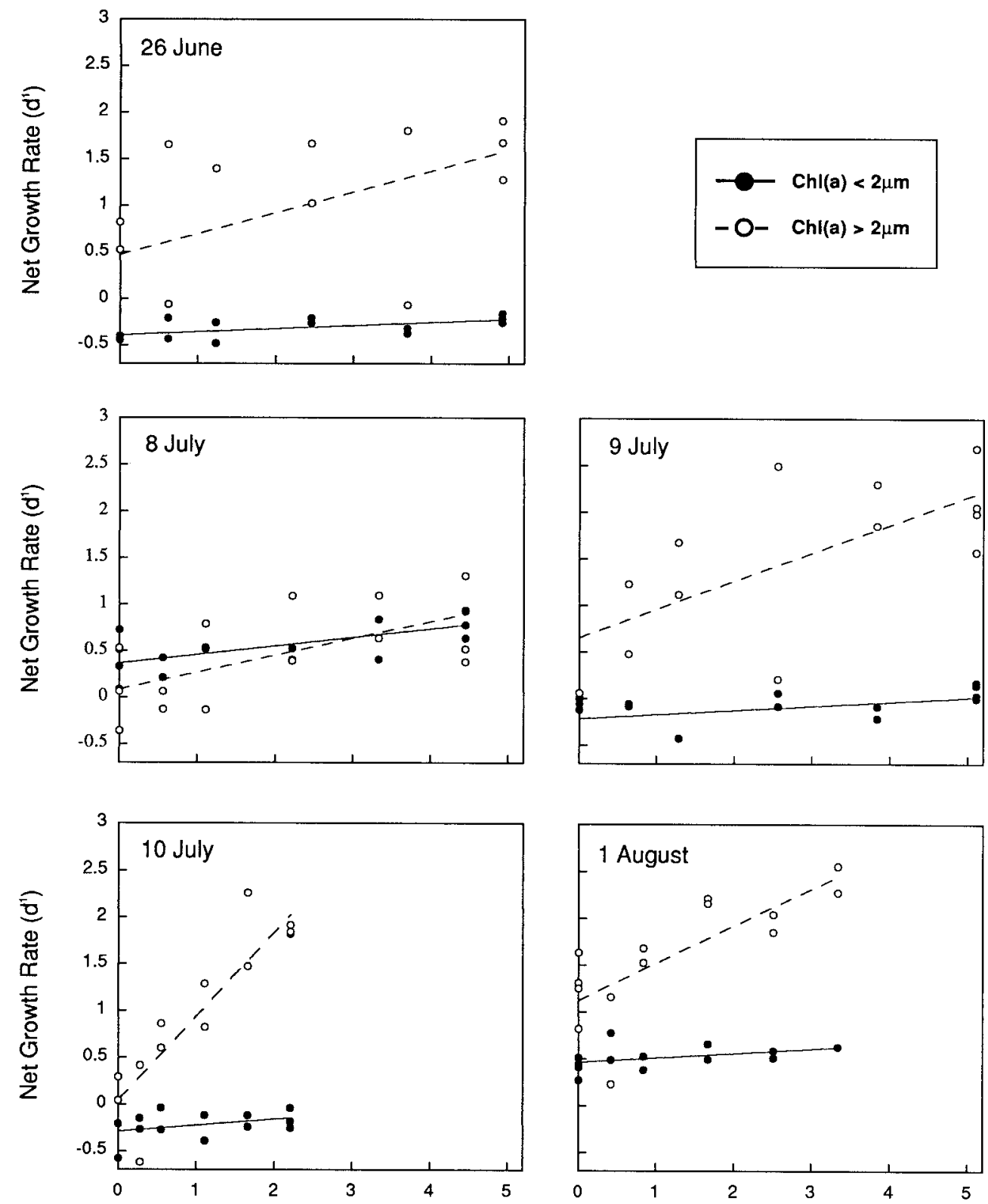

Fig. 4. Effects of zooplankton grazer biomass ( $\mathrm{mg}$ dry $\mathrm{wt} \mathrm{L}^{-1}$ ) on net growth rates of $<2-\mu \mathrm{m}$ and $>2-\mu \mathrm{m} C h l a$ size fractions in the subtropical north Pacific. Parameter estimates and correlation coefficients from least-squares linear regressions of these data are presented in Table 2.

tioned water samples by the MiniCap method, Wikner and Hagström (1988) noted highest bacterivore activity in 3- and $5-\mu \mathrm{m}$ filtered samples, a large drop-off in bacterivory in 8$\mu \mathrm{m}$ samples, and an increase to slightly higher than unfiltered control levels in $10-\mu \mathrm{m}$-filtered water. The present results agree reasonably with this predation pattern except with regard to the possible existence of a third active size fraction in the HNAN predatory chain. Because we did not incubate size-fractioned samples between 8 and $20 \mu \mathrm{m}$, it is possible that an intermediate trophic level may have been missed. However, the $8-\mu \mathrm{m}$-filtered samples in the present study seem to reflect only a partial suppression of bacterivore ac- tivity rather that the dramatic predatory impact implied by the results of Wikner and Hagström (1988) that would have been evident as net bacterial growth rates higher than unfiltered controls.

According to Hansen et al. (1994), the optimal predator: prey size ratio for copepods averages about 18 ; hence, the substantial size gap between 5- and 20- $\mu$ m HNAN and their consumers in the micro- and mesozooplankton is well within the range of food-gathering capabilities and mechanical constraints on such organisms. The breadth of the predatory influence of MESO on lower trophic levels most likely reflects the diversity of feeding guilds within this size category 

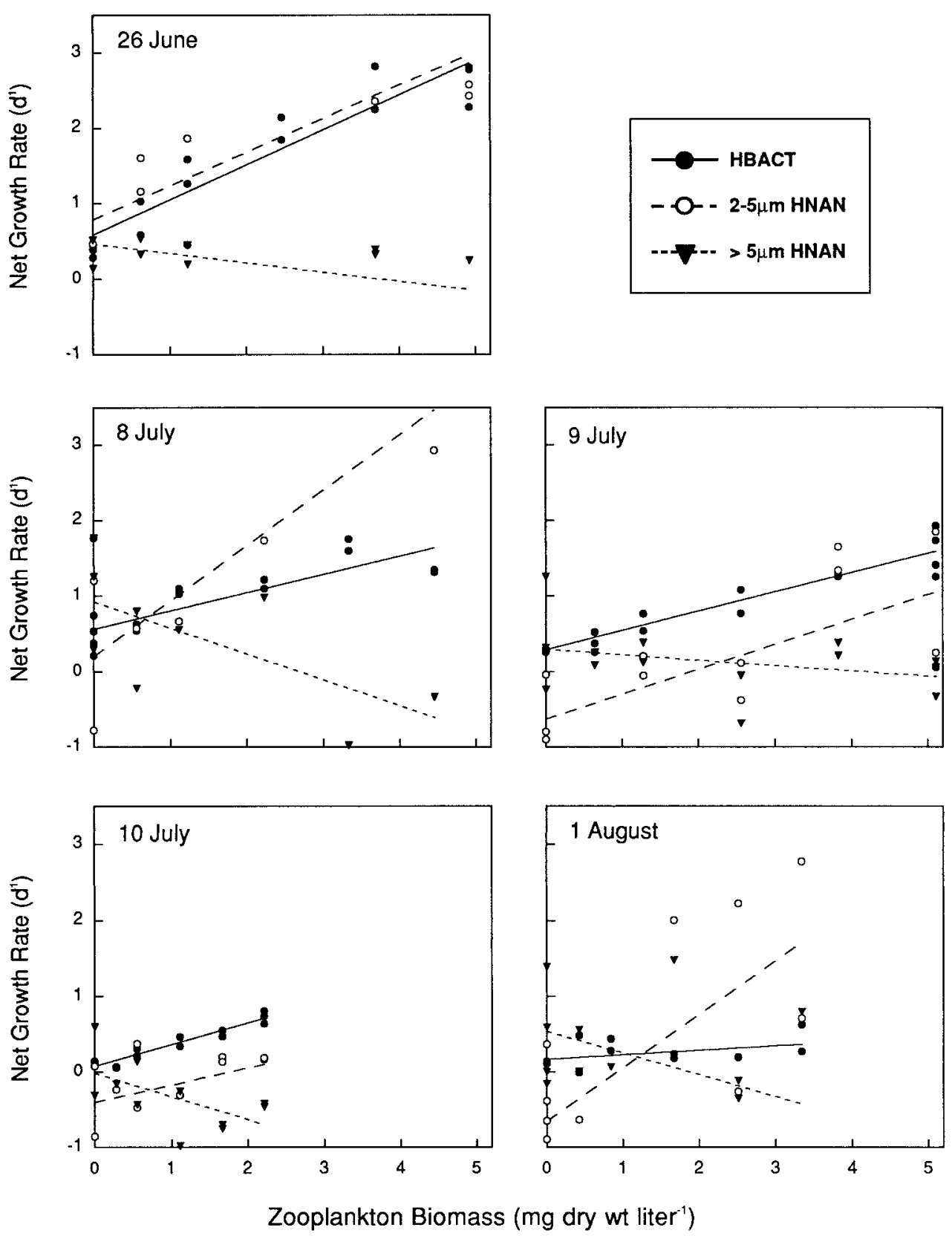

Fig. 5. Effects of zooplankton grazer biomass ( $\mathrm{mg}$ dry wt $\mathrm{L}^{-1}$ ) on net growth rates of heterotrophic bacteria (HBACT), $2-5-\mu \mathrm{m}$ heterotrophic nanoplankton (HNAN), and $>5-\mu \mathrm{m}$ HNAN in the subtropical north Pacific. Parameter estimates and correlation coefficients from least-squares linear regressions of these data are presented in Table 2.

rather than the eclectic feeding habits of individual animals. This group includes moderately small suspension-feeding species (e.g., Clausocalanus spp.) that presumably make their living feeding on prey $>5 \mu \mathrm{m}$ but probably not other copepods. At the other extreme are large predatory copepods, like Euchaeta rimana and Pleuromamma xiphias. Carnivorous copepod species are disproportionately abundant in oligotrophic waters (Hayward 1980; Ambler and Miller 1987), and their feeding preferences are consistent with the observed selection of copepodites over nauplii in our experiments (Fig. 3) (Yen 1985).

Indirect effects of mesozooplankton-Large zooplankton can potentially influence the dynamics of organisms at lower levels of the marine food web via cascading impacts on trophic intermediates or by the release of growth-stimulating substrates. In the present study, the negative effects of MESO and MICRO on $>5-\mu \mathrm{m}$ HNAN and their subsequent 
Table 2. Regression parameters and correlation coefficients $\left(R^{2}\right)$ for the relationships shown in Figs. 4 and 5. Intercept $=$ net growth rate $\left(\mathrm{d}^{-1}\right)$ in the absence of large grazers. Slope $=\Delta$ net growth rate of prey $\left(\mathrm{d}^{-1}\right)$ per $\mathrm{mg}$ dry wt $\mathrm{L}^{-1}$ increase in grazer biomass. Significance levels for slope estimates $\neq 0$ : $* P<0.05$; ** $P<0.01$; *** $P<0.001, \mathrm{~ns}=$ not significant. Significance of slope mean from nonparametric shortcut $t$-statistic (Tate and Clelland 1959; after Mosteller and Bush 1954).

\begin{tabular}{|c|c|c|c|c|c|}
\hline Parameter & Experiment & Intercept & Slope & $R^{2}$ & $P$ \\
\hline$<2-\mu \mathrm{m} \mathrm{Chl} a$ & $\begin{array}{l}26 \text { Jun } \\
8 \text { Jul } \\
9 \text { Jul } \\
10 \text { Jul } \\
1 \text { Aug } \\
\text { Mean slope }\end{array}$ & $\begin{array}{r}-0.39 \\
0.36 \\
-0.22 \\
-0.28 \\
0.46\end{array}$ & $\begin{array}{l}0.03 \\
0.09 \\
0.04 \\
0.06 \\
0.05 \\
0.05\end{array}$ & $\begin{array}{l}0.37 \\
0.47 \\
0.14 \\
0.13 \\
0.22\end{array}$ & $\begin{array}{l}\mathrm{ns} \\
* * \\
\mathrm{~ns} \\
\mathrm{~ns} \\
\mathrm{~ns} \\
* * *\end{array}$ \\
\hline$>2-\mu \mathrm{m} \mathrm{Chl} a$ & $\begin{array}{l}26 \text { Jun } \\
8 \text { Jul } \\
9 \text { Jul } \\
10 \text { Jul } \\
1 \text { Aug } \\
\text { Mean slope }\end{array}$ & $\begin{array}{l}0.47 \\
0.09 \\
0.65 \\
0.05 \\
1.10\end{array}$ & $\begin{array}{l}0.23 \\
0.18 \\
0.30 \\
0.89 \\
0.40 \\
0.40\end{array}$ & $\begin{array}{l}0.27 \\
0.39 \\
0.47 \\
0.80 \\
0.61\end{array}$ & $\begin{array}{c}\mathrm{ns} \\
* \\
* * \\
* * * \\
* * * \\
* *\end{array}$ \\
\hline Prochlorococcus & $\begin{array}{l}26 \text { Jun } \\
8 \text { Jul } \\
9 \text { Jul } \\
10 \text { Jul } \\
\text { Mean slope }\end{array}$ & $\begin{array}{r}0.15 \\
0.02 \\
-0.01 \\
0.09\end{array}$ & $\begin{array}{l}0.02 \\
0.03 \\
0.01 \\
0.02 \\
0.02\end{array}$ & $\begin{array}{l}0.15 \\
0.53 \\
0.14 \\
0.18\end{array}$ & $\begin{array}{l}\mathrm{ns} \\
* \\
\mathrm{~ns} \\
\mathrm{~ns} \\
* *\end{array}$ \\
\hline HBACT & $\begin{array}{l}26 \text { Jun } \\
8 \text { Jul } \\
9 \mathrm{Jul} \\
10 \mathrm{Jul} \\
1 \text { Aug } \\
\text { Mean slope }\end{array}$ & $\begin{array}{r}0.58 \\
0.56 \\
0.29 \\
-0.08 \\
0.17\end{array}$ & $\begin{array}{l}0.46 \\
0.24 \\
0.25 \\
0.29 \\
0.06 \\
0.26\end{array}$ & $\begin{array}{l}0.89 \\
0.74 \\
0.91 \\
0.92 \\
0.20\end{array}$ & $\begin{array}{c}* * * \\
* * * \\
* * * \\
* * * \\
\mathrm{~ns} \\
* *\end{array}$ \\
\hline $2-5-\mu \mathrm{m}$ HNAN & $\begin{array}{l}26 \mathrm{Jun} \\
8 \mathrm{Jul} \\
9 \mathrm{Jul} \\
10 \mathrm{Jul} \\
1 \mathrm{Aug} \\
\text { Mean slope }\end{array}$ & $\begin{array}{r}0.78 \\
0.20 \\
-0.63 \\
-0.40 \\
-0.65\end{array}$ & $\begin{array}{l}0.45 \\
0.73 \\
0.33 \\
0.23 \\
0.71 \\
0.49\end{array}$ & $\begin{array}{l}0.65 \\
0.55 \\
0.43 \\
0.15 \\
0.41\end{array}$ & $\begin{array}{c}* * \\
* \\
* * \\
\mathrm{~ns} \\
* \\
* * *\end{array}$ \\
\hline$>5-\mu \mathrm{m}$ HNAN & $\begin{array}{l}26 \mathrm{Jun} \\
8 \mathrm{Jul} \\
9 \mathrm{Jul} \\
10 \mathrm{Jul} \\
1 \mathrm{Aug} \\
\text { Mean slope }\end{array}$ & $\begin{array}{r}0.46 \\
0.93 \\
0.31 \\
-0.02 \\
0.54\end{array}$ & $\begin{array}{l}-0.12 \\
-0.34 \\
-0.07 \\
-0.31 \\
-0.29 \\
-0.23\end{array}$ & $\begin{array}{l}0.27 \\
0.42 \\
0.11 \\
0.34 \\
0.16\end{array}$ & $\begin{array}{c}\mathrm{ns} \\
* \\
\mathrm{~ns} \\
\mathrm{~ns} \\
\mathrm{~ns} \\
* * *\end{array}$ \\
\hline
\end{tabular}

positive impacts on 2-5- $\mu \mathrm{m}$ HNAN and $>2-\mu \mathrm{m}$ Chl $a$ are consistent with the expectations of predator-prey cascades. However, increasing the biomass and grazing of MESO and MICRO also resulted in enhanced growth of organisms $<2$ $\mu \mathrm{m}$, which is not consistent with the expected predatory chain effect from increased activity of $2-5-\mu$ m HNAN, the direct consumers of bacteria.

In the present experiments, we took care to minimize stimulatory effects on phytoplankton growth from mesozooplankton nutrient excretion by incubating our bottles under low light conditions (i.e., reduced growth potential) and by adding excess nutrients to all treatments. However, because of the diversity of compounds involved and their potentially large impact on the size structure of bacterial populations when given in excess, we made no attempt to control for the release of dissolved organic substrates. Even if released by zooplankton grazers at normal biomass-specific rates, the fluxes of organic substrates would have been greatly enhanced due to the high zooplankton biomass in our experiments. In addition, exudation of dissolved organic substrates may have been higher than normal due to stress or damage of some of the animals during net capture, despite our efforts to minimize such effects. In retrospect, differential release of organic substrates among our grazing treatments probably resulted in the positive relationship between mesozooplankton biomass and growth rates of bacterial populations. This explanation is consistent with the relatively high positive response of HBACT compared to the more phototrophic Prochlorococcus; however, the results also suggest a limited ability of Prochlorococcus to benefit from organic substrates under low light conditions. In both of these cases, the stimulatory effects of organic excretion appeared to have outweighed the expected negative impact of the top-down trophic cascade. If this is so, the bottom-up stimulation of bacterial populations added to, and therefore exaggerated, the net positive trophic cascade effect on bacteriovores (2$5-\mu \mathrm{m}$ HNAN). By similar reasoning, the exaggerated enhancement of $2-5-\mu \mathrm{m}$ prey by MESO excretion would have partially offset, and therefore understated, the net negative predatory impact of MESO on $>5-\mu \mathrm{m}$ HNAN. This complicated interplay between bottom-up and top-down effects likely explains why MESO grazing cascade appeared to exert a twofold stronger impact on $2-5-\mu$ m HNAN $(+0.49 \mathrm{~L}$ $\mathrm{mg}$ dry $\mathrm{wt}^{-1} \mathrm{~d}^{-1}$, Table 2) than on their immediate predators, the $>5-\mu \mathrm{m}$ HNAN $\left(-0.23 \mathrm{~L} \mathrm{mg}\right.$ dry $\left.\mathrm{wt}^{-1} \mathrm{~d}^{-1}\right)$.

Even given confounding predatory and excretory effects, the overall indirect influences of mesozooplankton on microbial food web interactions in this oligotrophic open-ocean ecosystem are clearly very small. Routine monthly sampling at station ALOHA since 1994 has shown that the peak annual biomass of mesozooplankton occurs during summer months and rarely exceeds $10 \mu \mathrm{g}$ dry wt $\mathrm{L}^{-1}$, averaged over a 150-m euphotic zone (Landry et al. unpubl.). Consequently, at mean natural densities of zooplankton at the study site, MESO grazing effects on net growth rates of lower trophic levels are about two orders of magnitude lower on a per day basis than rate estimates in Table 2. To put it another way, a factor of two increase in mesozooplankton biomass, which is approximately the magnitude of the annual cycle, would result in a $<0.005 \mathrm{~d}^{-1}$ net change in growth rates of any of the prey categories examined. Thus, for organisms that grow at rates of at least half to one cell division per day (e.g., Liu et al. 1997), the consequences of mesozooplankton grazing would be relatively trivial. We hasten to add, however, that the present results only apply to the hard-bodied crustaceans that typically dominate the biomass in net collections in these waters. Appendicularians are present in the plankton but unlikely to function as grazers under the conditions of our experiments. Also absent are the impacts of relatively rare large salps. Pelagic tunicates generally have higher specific rates of water clearance and they feed closer to the base of the food web than copepods (e.g., Alldredge 1981; Diebel and Lee 1992; Madin et al. 1997). Consequently, their impacts would need to be considered to arrive at a full accounting of mesozooplankton grazing at the study site. 
Table 3. Level of significance between regression lines in the treatments tested $(* P<0.05$; ** $P<0.01 ;$ ns $=$ not significant $):$ MESO + DCM $(6 / 26$ and $7 / 9$ experiments with MESO and DCM water), MESO+SURF (7/8 and 8/1 experiments with MESO and surface water), SURF-DCM (7/8 and 7/9 experiments with surface and DCM water from same station and cruise) and MESO-MICRO (7/9 and 7/10 experiments with MESO and MICRO from same station and cruise).

\begin{tabular}{llcccc}
\hline \hline Fraction & \multicolumn{2}{c}{ MESO+DCM } & MESO+SURF & SURF-DCM & MESO-MICRO \\
\hline Total Chl $a$ & Slope & $\mathrm{ns}$ & $*$ & $\mathrm{~ns}$ & $*$ \\
& Intercept & $\mathrm{ns}$ & $* *$ & $* *$ & $*$ \\
$<2 \mathrm{Chl} a$ & Slope & $\mathrm{ns}$ & $\mathrm{ns}$ & $\mathrm{ns}$ & $\mathrm{ns}$ \\
& Intercept & $\mathrm{ns}$ & $\mathrm{ns}$ & $* *$ & $\mathrm{~ns}$ \\
HBACT & Slope & $* *$ & $* *$ & $\mathrm{~ns}$ & $\mathrm{~ns}$ \\
& Intercept & $\mathrm{ns}$ & $* *$ & $*$ & $*$ \\
$2-5$ HNAN & Slope & $\mathrm{ns}$ & $\mathrm{ns}$ & $\mathrm{ns}$ & $\mathrm{ns}$ \\
& Intercept & $* *$ & $*$ & $\mathrm{~ns}$ & $\mathrm{~ns}$ \\
$>5$ HNAN & Slope & $\mathrm{ns}$ & $\mathrm{ns}$ & $*$ & $\mathrm{~ns}$ \\
& Intercept & $\mathrm{ns}$ & $\mathrm{ns}$ & $*$ & $\mathrm{~ns}$ \\
\hline
\end{tabular}

The position of pelagic tunicates in marine food webs is similar in some respects, though not in terms of relative abundance, to that of cladocerans in freshwater ecosystems. Both can feed on cells as small as bacteria; indeed, freshwater cladocerans may be even more important consumers of bacteria than protozoans (Pace and Funke 1991; Vaqué and Pace 1992; Pace and Cole 1996). In addition, both also feed directly on a broad size range of prey, including most of the autotrophic cells in their respective environments as well as all the organisms constituting the protistan predatory chain on bacteria (e.g., Weisse et al. 1990; Pace and Vaqué 1994; Pace et al. 1998). The dominance of cladocerans in freshwater systems along with their direct feeding interactions on a broad spectrum of prey at the base of the food web makes the cascade responses to manipulations of higher trophic levels fundamentally different in small lake and open-ocean environments. The presence or absence of planktivorous fish, for example, can dramatically impact the base of freshwater systems through size-selective impacts on the composition of the mesozooplankton community (e.g., Carpenter et al. 1985; McQueen et al. 1986). At least in the oligotrophic open ocean, the more distant and diffuse coupling of copepods with lower trophic levels appears to act as a barrier to the transmission of comparable cascades in marine systems.

Implications for marine ecosystem modeling-As previously noted, one of the motivations for this study was to provide insight that might help in developing ecosystem models for JGOFS time-series programs in the subtropical Pacific (HOT) and Atlantic (BATS-Bermuda Atlantic Time-series Study) Oceans. Routine data collection at these sites includes dissolved inorganic and organic constituents of seawater, bacterial populations, phytoplankton pigments, and mesozooplankton abundance and biomass, as well as primary production and sediment trap fluxes. However, because data constraints do not exist for intermediate trophic levels, the net magnitudes and directions of grazing impacts on bacteria and chlorophyll from the present study are relevant for parameterizing these poorly known trophic link- ages and for defining how a realistic model should respond to top-down forcing.

One implication from the present study is that direct functional response relationships cannot adequately represent the interactions of mesozooplankton with primary producers in the oligotrophic open oceans. Such constructs (typically Michaelis-Menton or Ivlev functions) are used effectively in models of rich temperate and coastal systems where the feeding of large zooplankton (e.g., Calanus) on large phytoplankton is a major trophic pathway (e.g., Steele 1974). However, the basic Calanus submodel cannot be readily translated to most regions of the open ocean, even with appropriate allometric scaling (e.g., Doney et al. 1996). The grazing impact of oceanic zooplankton combines the effects of numerous subdominant species filtered through varying trophic layers and thus should bear little resemblance to the functional response of any known consumer. From the present results, but counterintuitive to models with direct trophic coupling, phytoplankton in the subtropical Pacific respond positively, not negatively, to enhanced abundance of the mesozooplankton community. More importantly, within the natural range of seasonal abundances and interannual variability, the impact of mesozooplankton on intermediate trophic levels is sufficiently weak and broadly distributed to have little net direct or indirect influence on the base of the food web. For areas such as the central Pacific, mesozooplankton might be usefully incorporated into model closure terms. In principle, the aggregate grazing function would be linked to observed patterns in mesozooplankton biomass, avoiding ambiguous and arbitrary death functions (e.g., Landry 1976; Steele and Henderson 1992), and parameterized to give desired model products (e.g., fecal export flux) without significantly altering the dynamics of lower trophic levels.

The present results also suggest that important control points in the smaller size components of natural systems may not be accurately represented in current models. Control of the lower levels of phytoplankton and bacterial stocks in the oceans is a case in point, and one very relevant to the extremely oligotrophic waters of the subtropical North Pacific. 
Most models of marine plankton systems use feeding thresholds to maintain stability at low levels of phytoplankton abundance (e.g., Steele 1974; Frost 1993; Doney et al. 1996). However, laboratory studies offer little, if any, empirical evidence for threshold feeding among protistan consumers (Strom et al. in prep.), and the present experiments suggest that an entirely different stabilizing mechanism operates within natural microbial communities. For instance, when larger protists in the predatory chain were removed by size fractionation at $5 \mu \mathrm{m}$, the dominant phytoplankter (Prochlorococcus) was driven significantly and rapidly below initially low concentrations by the grazing of smaller $(<5-\mu \mathrm{m})$ protists (Fig. 1). Thus, at least in this example, predatory pressure from above (top-down control), rather than the inherent behavior of the dominant herbivore, determined the extent to which prey were exploited at low concentrations. Details of the predatory interactions among protists, including coupled responses in the trophic hierarchy, mixotrophy, selection and size plasticity, and recycling feedbacks to phytoplankton and bacteria, clearly hold the key to a better understanding of the structure, function, and stability of open ocean communities. Major progress is needed in these areas to advance marine ecosystem modeling beyond its present primitive state.

\section{References}

AlldREDGE, A. L. 1981. The impact of appendicularian grazing on natural food concentrations in situ. Limnol. Oceanogr. 26: 247257.

AmbleR, J. W. AND C. B. Miller. 1987. Vertical habitat-partitioning by copepodites and adults of subtropical oceanic copepods. Mar. Biol. 94: 561-577.

Azam, F., T. Fenchel, J. G. Field, J. S. Gray, L. A. Meyer-Reil AND F. ThingSTAD. 1983. The ecological role of water-column microbes in the sea. Mar. Ecol. Prog. Ser. 10: 257-263.

Beers, J. R., F. M. H. ReID, and G. L. Stewart. 1975. Microzooplankton of the North Pacific central gyre. Population structure and abundance, June 1973. Int. Revue ges. Hydrobiol. 60: 607-638.

Berggreen, U., B. Hansen, and T. Kiørboe. 1988. Food size spectra ingestion and growth of the copepod Acartia tonsa during development: Implications for determination of copepod production. Mar. Biol. 99: 341-352.

Campbell, L., H. Liu, H. A. Nolla, and D. Vaulot. 1997. Annual variability of phytoplankton and bacteria in the subtropical North Pacific Ocean at Station ALOHA during the 1991-1994 ENSO event. Deep-Sea Res. I 14: 167-192.

- H. A. Nolla, AND D. Vaulot. 1994. The importance of Prochlorococcus to community structure in the central North Pacific Ocean. Limnol. Oceanogr. 39: 954-961.

- AND D. VAULOT. 1993. Photosynthetic picoplankton community structure in subtropical the subtropical North Pacific Ocean near Hawaii (station ALOHA). Deep-Sea Res. I 40: 2043-2060.

Carpenter, S. R., J. F. Kitchell, and J. R. Hodgson. 1985. Cascading trophic interactions and lake productivity. BioScience 35: 634-639.

Cho, B. C., And F. AzAm. 1990. Biogeochemical significance of bacterial biomass in the ocean's euphotic zone. Mar. Ecol. Prog. Ser. 63: 253-259.

Conover, R. J. 1982. Interactions between microzooplankton and other plankton organisms. Ann. Inst. Oceanogr. (Paris) 58 (Suppl): 31-46.

Dayton, P. K., S. F. Thrush, M. T. Agrady, and R. J. Hofman. 1995. Environmental effects of marine fishing. Aquat. Conser. Mar. Freshwater Ecosyst. 5: 205-232.

Diebel, D., AND S. H. LeE. 1992. Retention efficiency of sub-micrometer particles by the pharyngeal filter of the pelagic tunicate Oikopleura vanhoeffeni. Mar. Ecol. Prog. Ser. 81: 25-30.

Doney, S. C., D. M. Glover, and R. G. NajJar. 1996. A new coupled, one-dimensional biological-physical model for the upper ocean: Applications to the JGOFS Bermuda Atlantic Time-series Study (BATS) site. Deep-Sea Res. II 43: 591-624.

Frost, B. W. 1972. Effects of size and concentration of food particles on the feeding behavior of the marine planktonic copepod Calanus pacificus. Limnol. Oceanogr. 17: 805-815.

- 1993. A modeling study of processes regulating plankton standing stock and production in the open subarctic Pacific Ocean. Prog. Oceanogr. 32: 17-56.

Fuhrman, J. A., T. D. Sleeter, C. A. Carlson, and L. M. ProcTOR. 1989. Dominance of bacterial biomass in the Sargasso Sea and its ecological implications. Mar. Ecol. Prog. Ser. 57: 207-217.

Hansen, B., P. K. Buørnsen, And P. J. Hansen. 1994. The size ratio between planktonic predators and their prey. Limnol. Oceanogr. 39: 395-403.

HAYWARD, T. L. 1980. Spatial and temporal feeding patterns of copepods from the North Pacific central gyre. Mar. Biol. 58: 295-309.

Hurtt, G. C., And R. A. Armstrong. 1996. A pelagic ecosystem model calibrated with BATS data. Deep-Sea Res. II 43: 653683.

Karl, D. M., AND R. LuKas. 1996. The Hawaii Ocean Time-series (HOT) program: Background, rationale and field implementation. Deep-Sea Res. II 43: 129-156.

Kerfoot, W. C. 1987. Cascading effects and indirect path-ways, p. 57-70. In W. C. Kerfoot and A. Sih [eds.], Predation: Direct and indirect impacts on aquatic communities. New England.

LANDRY, M. R. 1976. The structure of marine ecosystems: An alternative. Mar. Biol. 35: 1-7.

- 1978. Predatory feeding behavior of a marine copepod Labidocera trispinosa. Limnol. Oceanogr. 23: 1103-1113.

Lawson, L. L., E. E. Hofmann, And Y. H. SpITZ. 1996. Time series sampling and data assimilation in a simple marine ecosystem model. Deep-Sea Res. II 43: 625-651.

LEHMAN, J. T. 1980. Release and cycling of nutrients between planktonic algae and herbivores. Limnol. Oceanogr. 25: 620632.

Letelier, R. M., R. R. Bidigare, D. V. Hebel, And M. Ondrusek. 1993. Temporal variability of phytoplankton community structure based on pigment analysis. Limnol. Oceanogr. 38: 14201437.

LiU, H., H. A. Nolla, ANd L. CAmpBell. 1997. Prochlorococcus growth rate and contribution to primary production in the equatorial and subtropical North Pacific Ocean. Aquat. Microb. Ecol. 12: 39-47.

Madin, L. P., J. E. Purcell, And C. B. Miller. 1997. Abundance and grazing effects of Cyclosalpa bakeri in the subarctic $\mathrm{Pa}$ cific. Mar. Ecol. Prog. Ser. 157: 175-183.

Mazumder, A., W. D. TaYlor, D. J. McQueen, and D. R. S. LEAN. 1990. Effects of fish and plankton on lake temperature and mixing depth. Science 247: 312-315.

McQueen, D. J., J. R. Post, And E. L. Mills. 1986. Trophic relationships in freshwater pelagic ecosystems. J. Fish. Aquat. Sci. 43: 1571-1581.

Monger, B. C., And M. R. LANDry. 1993. Flow cytometric anal- 
ysis of marine bacteria using Hoechst 33342. Appl. Environ. Microbiol. 59: 905-911.

Mosteller, F., AND R. R. Bush. 1954. Selected quantitative techniques. Handbook of social psychology: Theory and method. Addison-Wesley.

Myers, R. A., J. A. Hutchings, and N. J. Barrowman. 1997. Why do fish stocks collapse? The example of cod in Atlantic Canada. Ecol. Appl. 7: 91-106.

PACE, M. L., AND J. J COLE. 1996. Regulation of bacteria by resources and predation tested in whole-lake experiments. Limnol. Oceanogr. 41: 1448-1460.

- - AND S. R. CARPENTER. 1998. Trophic cascades and compensation: Differential responses of microzooplankton in whole-lake experiments. Ecology 79: 138-152.

-, AND E. Funke. 1991. Regulation of planktonic communities by nutrients and hervibores. Ecology 72: 904-914.

, AND D. Vaqué. 1994. The importance of Daphnia in determining mortality rates of protozoans and rotifers in lakes. Limnol. Oceanogr. 39: 985-996.

Pauly, D., V. Christensen, J. Dalsgatrd, R. Froese, and F. TORRES. 1998. Fishing down marine food webs. Science 279: 860-863.

Rassoulzadegan, F., AND M. ETIEnNe. 1981. Grazing rates of the tintinnid Stenosemella ventricosa (Clap and Lachm) Jorg. on the spectrum of the naturally occurring particulate matter from a Mediterranean neritic area. Limnol. Oceanogr. 26: 258-270.

SHERR, E., AND B. SHERR. 1988. Role of microbes in pelagic food webs: A revised concept. Limnol. Oceanogr. 33: 1225-1227. , AND - 1993. Preservation and storage of samples for enumeration of heterotrophic protists, p. 207-212. In P. F. Kemp, B. F. Sherr, E. B. Sherr, and J. C. Jonathan [eds.], Handbook of methods in aquatic microbial ecology. Boca Raton (USA). and G.-A. Paffenhöfer. 1986. Phagotrophic protozoa as food for metazoans: A "missing" trophic link in marine pelagic food webs? Mar. Microb. Food Webs 1: 61-80.

SteEle, J. H. 1974. The structure of marine ecosystems. Harvard Univ. Press.

, AND E. M. Henderson. 1992. The role of predation in plankton models. J. Plankton Res. 114: 157-172.

Strickland, J. D. H., AND T. R. PARSONS. 1972. A practical handbook of seawater analysis. Ottawa, Canada.

TAte, M. W., AND R. C. Clelland. 1959. Nonparametric and shortcut statistics in the social, biological and medical sciences. Interstate Printers.

Vaqué, D., And M. L. Pace. 1992. Grazing on bacteria by flagellates and cladocerans in lakes with contrasting food-web structure. J. Plankton Res. 14: 307-321.

Vaulot, D., C. Courties, and F. Partensky. 1989. A simple method to preserve marine oceanic phytoplankton for flow cytometric analyses. Cytometry 10: 629-635.

WeISSE, T., AND OTHERS. 1990. Response of the microbial loop to the phytoplankton spring bloom in a large prealpine lake. Limnol. Oceanogr. 35: 781-794.

WiKNER, J., AND A. HAGSTRÖM. 1988. Evidence for a tightly coupled nanoplanktonic predator-prey link regulating the bacterivores in marine environment. Mar. Ecol. Prog. Ser. 137: 137145.

YEN, J. 1985. Selective predation by the carnivorous marine copepod Euchaeta elongata: Laboratory measurements of predation rates verified by field observations of temporal and spatial feeding patterns. Limnol. Oceanogr. 30: 577-597.

Received: 30 July 1998

Accepted: 15 March 1999

Amended: 20 April 1999 